\title{
Determination of Chemical Stability of Propellants Using the Vacuum Stability Test Method
}

\author{
Bojana Fidanovski ${ }^{1)}$ \\ Mirjana Dimić ${ }^{1)}$ \\ Aleksandar Milojkovic ${ }^{1)}$ \\ Vesna Rodic ${ }^{1)}$
}

\begin{abstract}
This paper includes the results of the examination of the single base propellants, double base propellants and double base rocket propellants with the Czech Vacuum Stability Test STABIL. For this method the main term was to analyze and define the best options for preparation of the samples, selection of the optimal mass of the samples and conditions of examination. Chemical stability of these samples was determined according to the STANAG 4556 standard method.
\end{abstract}

Key words: propellants, single base propellants, double base propellants, double base rocket propellant, chemical stability, testing method, testing results.

\section{Introduction}

I MPORTANT information about the behavior of energetic materials powder, single base propellants and double base propellants, double base rocket propellants etc., is based on the chemical stability. This information is essential to a safe production, handling and disposal. Method for determining chemical stability can be used to predict life time and to choose the adequate storage conditions. Chemical stability is an ability to keep chemical properties in the defined criteria as long as possible.

There are several types of powder and double base rocket propellants. The basic energetic components of all of them are nitro esters (nitrocellulose and nitroglycerin). Depending on the purpose, in order to achieve the desired properties, double base rocket propellants may also contain other additives. Thermal decomposition of these nitro esters starts from the very beginning of the production of nitrocellulose (NC) and nitroglycerin (NG), it is present in the production of double base rocket propellants, and it continues long after their preparation, during the storage [1]. The reaction of thermal decomposition of nitrocellulose begins with hemolytic tearing of the $\mathrm{CO}-\mathrm{NO}_{2}$ bond

$\left(\mathrm{RO}-\mathrm{NO}_{2} \rightarrow \mathrm{RO}^{\circ}+\mathrm{NO}_{2}{ }^{\circ}\right)$. This reaction forms as products free radicals, $\mathrm{RO}^{\circ}$ and $\mathrm{NO}_{2}{ }^{\circ}$, which then recombines immediately and attacks the molecular chains of nitrocellulose and nitroglycerine, the conduct of secondary reactions, each of them takes place at its own speed and with the exothermic effect [2-4].

Nitrogen oxides occur as degradation products. They cause further autocatalytic degradation of double-base propellants at the storage temperatures. This degradation can lead to a spontaneous combustion of double base propellants. In that case, double base propellants should be removed promptly from the warehouse or from the ammunition, to avoid this very dangerous situation. In order to predict when such situations might occur, different tests of stability were developed. There are several classical methods, and the most widely used methods that specify the chemical stability of energetic materials are manometric methods.

For about a century, a variety of vacuum methods has been used for this purpose. Among the best known today are the isothermal manometric method in the Russian version $[5,6]$ and the American vacuum stability test. The American vacuum stability test, however, is more suitable for the technical assessment of an explosive's stability [7-9]. In the former Czechoslovakia, a manometric method was developed [10], which is known under the name STABIL; it can be considered- to a certain extent- to be an automatic version of the American vacuum stability test [11]. This method was designed for the technological checking of the quality in the production of energetic materials, Fig.1.

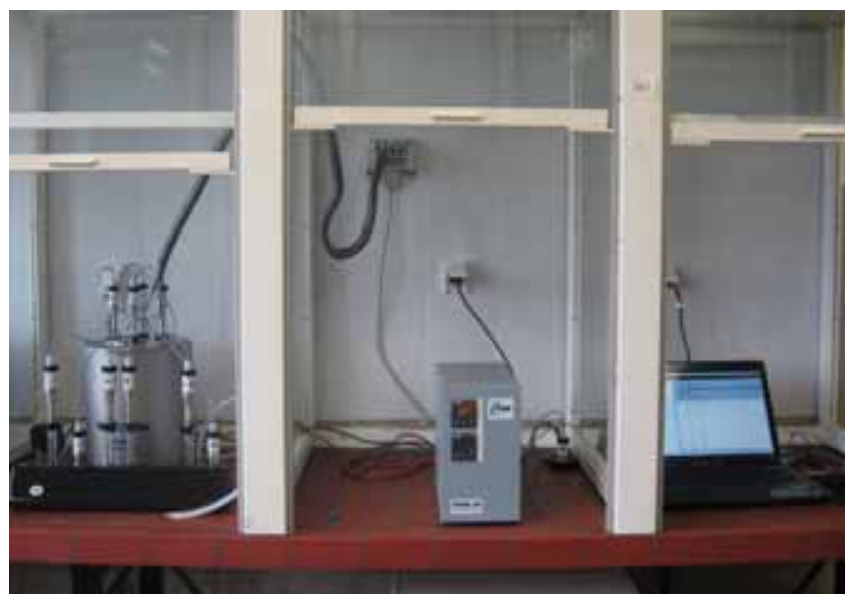

Figure 1. Vacuum stability test, STABIL

\footnotetext{
1) Military Technical Institute (VTI), Ratka Resanovića 1, 11132 Belgrade, SERBIA

Correspondence to: Bojana Fidanovski; e-mail: b.fidanovski@gmail.com
} 
In addition to the instrumental, there are classical methods of chemical stability for single and double base propellants, and for double base rocket propellants. Those classical methods are: Heating at $100^{\circ} \mathrm{C}$, Methyl violet method at $134.5^{\circ} \mathrm{C}$ (for single base propellants), and at $120^{\circ} \mathrm{C}$ (for double base propellants and double base rocket propellants). These methods are based on the accelerated degradation of powder and propellants and the quantitative monitoring of the released nitrogen oxides.

All these methods, classical and instrumental, are important for interpretation of the results and for giving an opinion about the chemical stability [12].

Therefore, the goal of this work is to use the Vacuum stability test for analyzing the chemical stability of single base and double base propellants and double base rocket propellants, by using the STANAG 4556 standard method.

\section{Experiments and methods}

In order to determinate the chemical stability, it is necessary to go through the following stages:

- Selection of the samples of single and double base propellants and double base rocket propellants;

- Preparation of the samples;

- Application of classical methods for testing the chemical stability of the samples;

- Application of vacuum stability test - chemical stability of the samples;

- Comparative analysis of the chemical stability of all tests results according to the defined criteria.

Samples of the single base and double base propellants

The following samples were selected for the experiments: single base propellants - SBP-1, SBP-2, SBP3 , double base propellants -DBP-1, DBP-2 and double base rocket propellants - DBRP-1 and DBRP-2.

\section{Preparation of the samples}

Dimension of the samples: Single base propellants have a small rectangular form, approximately $2 \mathrm{~mm} \times 2 \mathrm{~mm}$. Because of that, they were used in their original shape. On the other hand, the samples of the double base propellants and double base rocket propellants were chopped into small pieces, dimension $2 \mathrm{~mm} \times 2 \mathrm{~mm}$.

Mass of the samples: Masses of the samples are defined in SORS 9373 for classical methods [13].

For Vacuum stability test the mass of the samples were measured approximately $1.000 \pm 0.0001 \mathrm{~g}$ and $2.000 \pm 0.0001 \mathrm{~g}$.

Drying time (only for the Vacuum stability test): Chopped samples were used with and without drying. For the dried samples the temperature of heating was $55^{\circ} \mathrm{C}$ to the $60^{\circ} \mathrm{C}$. And the time that the samples were on that temperature was 0 (undried), 60, 240, 960 minutes. After that, and before putting the sample in the instrument, they need to cool in desiccators to the room temperature, approximately 4 hours.

\section{Classical methods}

Testing of the chemical stability of the single and double base propellants and for double base rocket propellants using traditional methods was carried out in accordance with the applicable standard in the manner and methods described in [13].

Testing the chemical stability by the Methyl violet method at $134.5^{\circ} \mathrm{C}$ and $120^{\circ} \mathrm{C}$ and Heating at $100^{\circ} \mathrm{C}$ for all the samples was performed.

\section{STABIL vacuum stability test}

A modernized STABIL 20 apparatus was used for these measurements (manufactured by OZM Research, the error is $<1 \%$ ). Tests lasted for $2400 \mathrm{~min}$. The temperature for the isothermal measurements was $100^{\circ} \mathrm{C}$ for single base propellants, and for double base propellants the temperature was $90^{\circ} \mathrm{C}$, according to STANAG 4556 .

The special heating tubes, which are used for this method, length $140 \pm 5 \mathrm{~mm}$ and diameter $18 \mathrm{~mm}$, are with the steel male part of a ground metal joint. This part is welded to the transducer and includes a hole for gas extraction. The samples in evacuated glass test tubes were placed into the heating block for 40 hours and heated to the desired temperature. Pressure transducers continuously estimated the pressure increase in the glass tubes. The results were in form of time dependence of the gas pressure evolved per one gram sample.

The results were in form of time dependence of the gas volume evolved from $1 \mathrm{~g}$ sample per second (i.e. $V$ values in $\left.\mathrm{cm}^{3} \mathrm{~g}^{-1}\right)$ and corrected to standard conditions, according to equation (1) [14]:

$$
V=\left(V_{c}+V_{t}-\frac{m}{\rho}\right) \times\left(\frac{p_{2} \times 273}{273+t_{2}}-\frac{p_{1} \times 273}{273+t_{1}}\right) \times \frac{1}{1.013}
$$

Where:

$V_{c} \quad$ - the volume of transducer,

$V_{t} \quad$ - the volume of glass test tubes,

$M \quad$ - mass of the samples,

$P \quad$ - density,

$p_{1}, t_{1} \quad$ - pressure, temperature at the beginning of experiment,

$p_{2,} t_{2} \quad$ - pressure, temperature at the end of experiment.

\section{Results and discussion}

Results of testing the chemical stability of the samples DBRP-1 and DBRP-2 by the Method of heating at $100^{\circ} \mathrm{C}$, Methyl violet method at $120^{\circ} \mathrm{C}$ are shown in Table 1 .

Table 1. Results of testing the chemical stability of the samples of double base rocket propellants

\begin{tabular}{||c|c|c|c||}
\hline Methods & $\begin{array}{c}\text { SORS 9373/13 } \\
\text { Criteria }\end{array}$ & DBRP-1 & DBRP-2 \\
\hline \hline $\begin{array}{c}\text { Method of heating at } \\
100^{\circ} \mathrm{C} \text {, day }\end{array}$ & more than 4 & 9 & more than 8 \\
\hline $\begin{array}{c}\text { Methyl violet method at } \\
120^{\circ} \mathrm{C}, \text { min }\end{array}$ & at least 45 & 70 & 70 \\
\hline
\end{tabular}

Results of testing the chemical stability of the samples SBP1, SBP-2 and SBP-3 by the Method of heating at $100^{\circ} \mathrm{C}$, Methyl violet method at $134.5^{\circ} \mathrm{C}$ are shown in Table 2 .

Table 2. Results of testing the chemical stability of the samples of single base propellants

\begin{tabular}{|c|c|c|c|c||}
\hline Methods & $\begin{array}{c}\text { SORS 9373/13 } \\
\text { Criteria }\end{array}$ & SBP-1 & SBP-2 & SBP-3 \\
\hline \hline $\begin{array}{c}\text { Method of heating at } \\
100^{\circ} \mathrm{C} \text {, day }\end{array}$ & more than 6 & more than 10 & 9 & 10 \\
\hline $\begin{array}{c}\text { Methyl violet method } \\
\text { at } 134.5^{\circ} \mathrm{C}, \text { min }\end{array}$ & at least 50 & 70 & 69 & 72 \\
\hline
\end{tabular}

Based on the results of testing the chemical stability of the classical methods shown in Tables 1 and 2 and according to the shown criteria, the samples of double base rocket propellants and single base propellants are chemically stable.

Results of testing the chemical stability of the samples DBP-1 and DBP-2 by the Method of heating at $100^{\circ} \mathrm{C}$, Methyl violet method at $120^{\circ} \mathrm{C}$ are shown in Table 3 . 
Table 3. Results of testing the chemical stability of the samples of double base propellants

\begin{tabular}{||c|c|c|c|}
\hline Methods & $\begin{array}{c}\text { SORS 9373/13 } \\
\text { Criteria }\end{array}$ & DBP-1 & DBP-2 \\
\hline \hline $\begin{array}{c}\text { Method of heating at } \\
100^{\circ} \mathrm{C}, \text { day }\end{array}$ & at least 3 & 6 & 6 \\
\hline $\begin{array}{c}\text { Methyl violet method at } \\
120^{\circ} \mathrm{C}, \text { min }\end{array}$ & at least 45 & 55 & 51 \\
\hline
\end{tabular}

According to the results given in Table 3, for the samples of double base propellants and criteria for DBP, it can be said that DBP-1 and DBP-2 are chemically stable.

The criteria for single base and double base propellants for the chemical stability by using the method of Vacuum stability test are given in Table 4 [14].

Table 4. Criteria of the chemical stability for single base and double base propellants

\begin{tabular}{||c|c|c|c||}
\hline \hline Type & $\begin{array}{c}\text { Temperature of iso- } \\
\text { thermal measurement, } \\
{ }^{\circ} \mathrm{C}\end{array}$ & $\begin{array}{c}\text { Time of experi- } \\
\text { ment, minutes }\end{array}$ & $\begin{array}{c}\text { Criteria of chemical } \\
\text { stability*, } \\
\mathrm{cm} 3 \mathrm{~g}-1\end{array}$ \\
\hline \hline DBRP & 90 & 2400 & $\leq 1.2$ \\
\hline SBP & 100 & 2400 & $\leq 2$ \\
\hline DBP & 90 & 2400 & $\leq 1.2$ \\
\hline
\end{tabular}

Note:* corrected to standard conditions

Results of testing the chemical stability of DBRP-1 and DBRP-2 by vacuum stability at $90^{\circ} \mathrm{C}$ are shown in Tables 5 and 6.

Table 5. Results of testing the chemical stability of the sample of DBRP-2

\begin{tabular}{|c|c|c|c|c|c|}
\hline No. & $\begin{array}{c}\text { Drying time, } \\
\text { min }\end{array}$ & $\begin{array}{l}\text { Density, } \\
\mathrm{g} \mathrm{cm}^{-3}\end{array}$ & $\begin{array}{c}\text { Mass, } \\
\mathrm{g}\end{array}$ & $\begin{array}{c}\mathrm{V}, \\
\mathrm{cm}^{3}\end{array}$ & $\begin{array}{c}\mathrm{V}, \\
\mathrm{cm}^{3} \mathrm{~g}^{-1}\end{array}$ \\
\hline 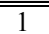 & \multirow{4}{*}{240} & \multirow{4}{*}{1.600} & $\begin{array}{l}1.007 \\
\end{array}$ & (1.245 & 1.236 \\
\hline 2 & & & 0.995 & 0.989 & 0.994 \\
\hline 3 & & & 1.002 & 1.199 & 1.196 \\
\hline 4 & & & 1.000 & 0.899 & 0.899 \\
\hline$\overline{5}$ & \multirow{4}{*}{240} & \multirow{4}{*}{1.600} & 2.002 & 1.835 & 0.917 \\
\hline 6 & & & 2.000 & 1.820 & 0.910 \\
\hline 7 & & & 2.003 & 1.871 & 0.936 \\
\hline 8 & & & 2.007 & 1.859 & 0.929 \\
\hline
\end{tabular}

Table 6. Results of testing the chemical stability of the sample of DBRP-1

\begin{tabular}{|c|c|c|c|c|c|}
\hline No. & $\begin{array}{l}\text { Drying } \\
\text { time, } \\
\text { min }\end{array}$ & $\begin{array}{l}\text { Density, } \\
\mathrm{g} \mathrm{cm}^{-3}\end{array}$ & $\begin{array}{c}\text { Mass, } \\
\mathrm{g}\end{array}$ & $\begin{array}{l}\mathrm{V}, \\
\mathrm{cm}^{3}\end{array}$ & $\begin{array}{c}\mathrm{V} \\
\mathrm{cm}^{3} \mathrm{~g}^{-1}\end{array}$ \\
\hline 1 & \multirow{4}{*}{240} & \multirow{4}{*}{1.680} & 1.003 & 0.687 & 0.685 \\
\hline 2 & & & 1.001 & 0.789 & 0.788 \\
\hline 3 & & & 0.992 & 0.559 & 0.563 \\
\hline 4 & & & 1.000 & 1.012 & 1.012 \\
\hline 5 & \multirow{4}{*}{240} & \multirow{4}{*}{1.680} & 1.999 & 0.914 & 0.457 \\
\hline 6 & & & 2.002 & 0.939 & 0.469 \\
\hline 7 & & & 1.999 & 0.950 & 0.475 \\
\hline 8 & & & 2.001 & 0.917 & 0.458 \\
\hline
\end{tabular}

In Tables 5 and 6, with the mass of approximately $1 \mathrm{~g}$, the samples showed huge disaccord to each other. Results from the samples of DBRP-2 of mass of $1 \mathrm{~g}$ are above the Table 4 criteria. On the other hand, the results for the samples of DBRP-1 with the same weight are in the criteria level.

Regarding the samples of $2 \mathrm{~g}$, it can be seen that the evolved gas volumes are more similar to each other and still in the range.

Results of testing the chemical stability of SBP-1, SBP-2 and SBP-3 by vacuum stability at $100^{\circ} \mathrm{C}$ are shown in Tables 7-9.
Table 7. Results of testing the chemical stability of the sample SBP-1

\begin{tabular}{|c|c|c|c|c|c|}
\hline No. & $\begin{array}{c}\text { Drying time, } \\
\text { min }\end{array}$ & $\begin{array}{l}\text { Density, } \\
\mathrm{g} \mathrm{cm}^{-3}\end{array}$ & $\begin{array}{c}\text { Mass, } \\
\mathrm{g}\end{array}$ & $\begin{array}{l}\mathrm{V}, \\
\mathrm{cm}^{3}\end{array}$ & $\begin{array}{c}\mathrm{V}, \\
\mathrm{cm}^{3} \mathrm{~g}^{-1}\end{array}$ \\
\hline 1 & \multirow{4}{*}{0} & \multirow{4}{*}{0.800} & $\begin{array}{c}0.997 \\
\end{array}$ & 0.898 & 0.901 \\
\hline 2 & & & 0.999 & 0.906 & 0.906 \\
\hline 3 & & & 1.998 & 1.128 & 0.565 \\
\hline 4 & & & 2.001 & 1.083 & 0.542 \\
\hline$\overline{5}$ & \multirow{4}{*}{60} & \multirow{4}{*}{0.800} & 0.999 & 0.845 & 0.845 \\
\hline 6 & & & 1.002 & 0.791 & 0.790 \\
\hline 7 & & & 1.993 & 1.189 & 0.597 \\
\hline 8 & & & 1.997 & 1.174 & 0.588 \\
\hline 9 & \multirow{4}{*}{240} & \multirow{4}{*}{0.800} & $\begin{array}{l}1.004 \\
\end{array}$ & 0.911 & 0.907 \\
\hline 10 & & & 0.975 & 0.744 & 0.764 \\
\hline 11 & & & 1.997 & 1.215 & 0.608 \\
\hline 12 & & & 1.995 & 1.193 & 0.593 \\
\hline 13 & \multirow{2}{*}{960} & \multirow{2}{*}{0.800} & $\begin{array}{ll}1.000 \\
\end{array}$ & 0.682 & 0.682 \\
\hline 14 & & & 2.001 & 1.051 & 0.525 \\
\hline
\end{tabular}

In Table 7 all the results for the sample SBP-1 are satisfactory, according to the criteria (Table 4). It means that no matter what was the drying time, 60 minutes, 240 minutes or 960 minutes, or even the sample is undried; the volumes of the evolved gas from this sample are all regular. Although, both weight that we chose, one or two grams of the samples, showed analogy with the criteria.

Table 8. Results of testing the chemical stability of the sample SBP-2

\begin{tabular}{|c|c|c|c|c|c|}
\hline No. & $\begin{array}{c}\text { Drying time } \\
\text { min }\end{array}$ & $\begin{array}{l}\text { Density, } \\
\mathrm{g} \mathrm{cm}^{-3}\end{array}$ & $\begin{array}{c}\text { Mass, } \\
\mathrm{g}\end{array}$ & $\begin{array}{l}\mathrm{V} \\
\mathrm{cm}^{3}\end{array}$ & $\begin{array}{c}\mathrm{V} \\
\mathrm{cm}^{3} \mathrm{~g}^{-1}\end{array}$ \\
\hline 1 & \multirow{2}{*}{0} & \multirow{2}{*}{1.500} & 0.998 & 2.904 & 2.909 \\
\hline 2 & & & 1.892 & 4.518 & 2.388 \\
\hline 3 & \multirow{2}{*}{60} & \multirow{2}{*}{1.500} & 0.992 & 1.949 & 1.964 \\
\hline 4 & & & 1.960 & 2.917 & 1.488 \\
\hline 5 & \multirow{4}{*}{240} & \multirow{4}{*}{1.500} & 0.994 & 1.317 & 1.324 \\
\hline 6 & & & 1.008 & 1.429 & 1.417 \\
\hline 7 & & & 2.002 & 2.410 & 1.204 \\
\hline 8 & & & 2.009 & 2.439 & 1.214 \\
\hline 9 & \multirow{2}{*}{960} & \multirow{2}{*}{1.500} & 0.999 & 1.684 & 1.686 \\
\hline 10 & & & 1.957 & 2.399 & 1.226 \\
\hline
\end{tabular}

On the other hand, the results of experiments showed in Table 8 for the sample SBP-2 are partly dissatisfactory in regard to the criteria. Main problem for these samples are probably the age of the samples. Also, SBP-2 absorbs too much moisture and evaporated residual solvent and, because of it, values of the evolved gas from sample are too big. Regardless of the drying time, the results obtained from the samples of $1 \mathrm{~g}$ do not satisfy the criteria. On the other hand, the ones obtained for the samples of $2 \mathrm{~g}$ and the drying time of 240 minutes satisfy the criteria, i. e., they are on the upper limit of the criteria.

Table 9. Results of testing the chemical stability of the sample SBP-3

\begin{tabular}{|c|c|c|c|c|c|}
\hline No. & $\begin{array}{c}\text { Drying time, } \\
\text { min }\end{array}$ & $\begin{array}{l}\text { Density, } \\
\mathrm{g} \mathrm{cm}^{-3}\end{array}$ & $\begin{array}{c}\text { Mass, } \\
\mathrm{g}\end{array}$ & $\begin{array}{c}\mathrm{V}, \\
\mathrm{cm}^{3}\end{array}$ & $\begin{array}{c}\mathrm{V}, \\
\mathrm{cm}^{3} \mathrm{~g}^{-1}\end{array}$ \\
\hline 1 & \multirow{2}{*}{0} & \multirow{2}{*}{1.500} & 0.993 & 2.270 & 2.287 \\
\hline 2 & & & 1.999 & 2.808 & 1.405 \\
\hline 3 & \multirow{4}{*}{60} & \multirow{4}{*}{1.500} & 0.995 & $\begin{array}{l}1.699 \\
\end{array}$ & 1.707 \\
\hline 4 & & & 1.003 & 2.281 & 2.274 \\
\hline 5 & & & 1.993 & 2.993 & 1.502 \\
\hline 6 & & & 2.000 & 2.512 & 1.256 \\
\hline 7 & \multirow{4}{*}{240} & \multirow{4}{*}{1.500} & 1.002 & 1.693 & 1.689 \\
\hline 8 & & & 0.994 & 1.749 & 1.763 \\
\hline 9 & & & 1.999 & 2.413 & 1.207 \\
\hline 10 & & & 2.002 & 2.398 & 1.197 \\
\hline 111 & \multirow{2}{*}{960} & \multirow{2}{*}{1.500} & 0.998 & 1.568 & 1.571 \\
\hline 12 & & & 2.003 & 2.476 & 1.236 \\
\hline
\end{tabular}

Results in Table 9 for SBP-3, several values are higher than the corresponding criteria. 
An increase of the evolved gas volume is obtained for $1 \mathrm{~g}$ dried during 60 minutes and for the non-treated samples, undried. It may be said that this sample has a similar problem as SBP-2.

The samples of two grams showed better correspondence with the criteria if we analyzed single base propellants from the point of view of stability.

Results of testing the chemical stability of DBP-2 and DBP-1 by vacuum stability at $90^{\circ} \mathrm{C}$ are shown in Tables 10 and 11 .

Table 10. Results of testing the chemical stability of the sample DBP-2

\begin{tabular}{|c|c|c|c|c|c|}
\hline No. & $\begin{array}{c}\text { Drying time, } \\
\min \end{array}$ & $\begin{array}{l}\text { Density, } \\
\mathrm{g} \mathrm{cm}^{-3}\end{array}$ & $\begin{array}{l}\text { Mass, } \\
\mathrm{g}\end{array}$ & $\mathrm{V}$ & $\begin{array}{c}\mathrm{V} \\
\mathrm{cm}^{3} \mathrm{~g}^{-1}\end{array}$ \\
\hline 1 & \multirow{4}{*}{0} & \multirow{4}{*}{0.700} & 0.991 & 0.605 & 0.605 \\
\hline 2 & & & 1.007 & 1.201 & 0.600 \\
\hline 3 & & & 2.002 & 1.227 & 0.613 \\
\hline 4 & & & 2.010 & 1.920 & 0.960 \\
\hline 5 & \multirow{4}{*}{240} & \multirow{4}{*}{0.700} & (1.003 & 0.641 & 0.641 \\
\hline 6 & & & 0.999 & 0.590 & 0.590 \\
\hline 7 & & & 2.001 & 1.230 & 0.615 \\
\hline 8 & & & 2.000 & 1.263 & 0.632 \\
\hline
\end{tabular}

Table 11. Results of testing the chemical stability of the sample DBP-1

\begin{tabular}{|c|c|c|c|c|c|}
\hline No. & $\begin{array}{c}\text { Drying time, } \\
\text { min }\end{array}$ & $\begin{array}{l}\text { Density, } \\
\mathrm{g} \mathrm{cm}^{-3}\end{array}$ & $\begin{array}{c}\text { Mass, } \\
\mathrm{g}\end{array}$ & $\begin{array}{l}\mathrm{V}, \\
\mathrm{cm}^{3}\end{array}$ & $\begin{array}{c}\mathrm{V}, \\
\mathrm{cm}^{3} \mathrm{~g}^{-1}\end{array}$ \\
\hline 1 & \multirow{4}{*}{0} & \multirow{4}{*}{0.670} & 1.001 & 0.606 & 0.606 \\
\hline 2 & & & 1.003 & 0.631 & 0.631 \\
\hline 3 & & & 2.004 & 1.021 & 0.510 \\
\hline 4 & & & 1.999 & 0.863 & 0.432 \\
\hline$\overline{5}$ & \multirow{4}{*}{$0 *$} & \multirow{4}{*}{0.670} & 1.000 & 0.628 & 0.628 \\
\hline 6 & & & 1.007 & 0.598 & 0.589 \\
\hline 7 & & & 2.000 & 1.101 & 0.550 \\
\hline 8 & & & 2.002 & 1.208 & 0.604 \\
\hline 9 & \multirow{4}{*}{60} & \multirow{4}{*}{0.670} & 1.011 & 0.525 & 0.525 \\
\hline 10 & & & 1.003 & 0.536 & 0.536 \\
\hline 11 & & & 1.997 & 0.969 & 0.485 \\
\hline 12 & & & 2.001 & 1.075 & 0.537 \\
\hline 13 & \multirow{4}{*}{240} & \multirow{4}{*}{0.670} & 1.003 & 0.491 & 0.491 \\
\hline 14 & & & 1.010 & 0.568 & 0.568 \\
\hline 15 & & & 2.001 & 1.020 & 0.510 \\
\hline 16 & & & 2.000 & 1.039 & 0.520 \\
\hline
\end{tabular}

On the other hand, double base propellants showed much better analogy with the criteria in regard to the samples of single base propellants.

In Table 10, we can see that values of the evolved gas volume from $1 \mathrm{~g}$ sample per second are very low. In this table we have several samples that were treated without drying. They were put in vacuum desiccators and left for one day. The result of that way of treatment shows not so good matching but, according to the criteria, they are acceptable. Samples of DBP-1, with the mass of two grams and the 240 minutes of dry time show the best mutual agreement.

Observing Table 11, in the row where two grams of samples were treated for 240 minutes, the same trend can be seen as it is in the table above, for the same conditional. The values of the evolved gas lie in a narrow range.

\section{Conclusion}

In the study of selecting the suitable methods for the chemical stability of the single base and double base propellants, a modification of the American vacuum isothermal stability test was used, the Czech system STABIL 20

The analysis showed that in the observation of each sample individually there is a deviation, which mostly depends on the age of powder, chemical composition, geometry of the propellant grain and technological process. If we look at this method from the standpoint of the chemical stability for the samples of single base propellants, SBP-1, SBP-2, SBP-3, this method indicates that these samples are on the boundary of chemically stable. For the samples of double base rocket propellants DBRP-2 and DBRP-1, the same conclusion, as it is above, can be seen. As opposed to the single base and double base rocket propellants, the samples of double base propellants, DBP-1 and DBP-2, showed an excellent matching with the criteria indicating their chemical stability.

If we look at all the tabular results of this study, we can find out that the mass of two grams is a better solution than the mass of one gram. The reason for this conclusion is that the samples are not homogeneous. Bigger mass of the sample used gives more relevant result. Also, we found out that the drying time of 240 minutes in the temperature from $55^{\circ} \mathrm{C}$ to the $60^{\circ} \mathrm{C}$ is optimal for all the samples (single and double base propellants). The explanation is simple, if we dry samples less than 240 minutes, the samples cannot relieve absorbed moisture and the evaporation of the residual solvent is incomplete. On the other hand, if we let samples more than 240 minutes, the chemical reactionthermal decomposition of nitro esters will start.

This investigation allowed using this method in an appropriate way and, what is more important, to write a document of the national impartment for our country Defense Standard of the Republic of Serbia [16].

\section{References}

[1] DIMIĆ,M., JELISAVAC,LJ., KARIŠIK,N., BAJRAMOVIĆ,D.: Correlation of Chemical Stability Assessment of Accelerated Aged Double-Base Propellants Using Stabilizer Depletion and Conventional Methods, International Scientific Conference on Defensive Technologies - OTEH 2011, 6-7 October 2011, Belgrade, SERBIA, ISBN 978-86-81123-50-8, 2011, pp. 337-342.

[2] KUO,K., SUMMERFIELD,M.: Fundamentals of Solid-propellant Combustion, Progress in Astronautics, Martin Summerfield Series Editor-in-Chief, 90, 1984, pp.181-190.

[3] BOHN,M.A., VOLK,F.: Aging Behavior of Propellants Investigated by Heat Generation, Stabilizer Consumption and Molar Mass Degradation, Propellants, Explos., Pyrotech., 1992, Vol.17, pp.171176.

[4] BOHN,M.A.: Methods and Kinetic Models for the Life Time Assessment of Solid Propellants, $87^{\text {th }}$ Symp. of the Propulsion and Energetic Panel of the AGARD: Service Life of Solid Propellant Systems, Athens, 1996

[5] ANDREEV,K.K., BELYAEV,A.F.: Teoriya vzryvchatykh veschestv (Theory of Explosives), Oborongiz, Moscow, 1960.

[6] GOL'BINDER,A.I., Laboratorniye raboty po kursu teorii vzryvchatykh veschestv (Laboratory Practice in the Theory of Explosives), Rosvuzizdat, Moscow, 1963, pp.9.

[7] ROSEN,A.M., SIMMONS,H.T.: Improved Apparatus and Techniques for the Measurement of the Vacuum Stability of Explosives, U.S. Govt. Rep. AD 226 940, Washington DC, 1959.

[8] SIMMONS,H.T: The Vacuum Thermal Stability Test for Explosives; Report NOLTR 70-142, U.S. Naval Ordnance Lab., White Oak, Oct. 1970, U.S. Govt. Rep. AD 718 806, Washington DC.

[9] HAUSELER,E.: Symp. Chem. Problems Connected Stab. Explos., Stockholm, May 1976, Sektion for Detonik och Fiirbrlnnig, Stockholm, p.34.

[10] KUČERA,V., VETLICK'Y,B.: Investigation of the decomposition processes in single-base propellants under vacuum using minicomputer-controlled automated apparatus, Propellants Explos. Pyrotech., 1985, Vol.10, p.65.

[11] BAYTOS,J.F.: High-temperature vacuum thermal stability test of explosives, Los Alamos Nstl. Lab., Sci. Lab. Rep. LA-5829MS, 1975.

[12] JELISAVAC,Lj.: Hemijska stabilnost $i$ vek upotrebe baruta $i$ 
raketnih goriva (Chemical stability and lifetime of the propellants), KumNTI, Vojnotehnički institut, Belgrade SERBIA, ISSN 18203418, ISBN 978-86-81123-31-7, 2009, Vol. XLIII, No.2.

[13] SORS 9373/13: Baruti i raketna goriva - KLASIČNE METODE ISPITIVANJA HEMIJSKE STABILNOSTI, Beograd, 2013.

[14] STANAG 4556: EXPLOSIVES: VACUUM STABILITY TEST Brussels: North Atlantic Treaty Organization, Military Agency for Standardization, 1999
[15] ROSEN,A.M.: NC-based energetic materials-Stability, decomposition and ageing, Presentation on the meeting Nitrocellulose-Supply, Ageing and Characterization, England, 2007

[16] SORS 9374/13: Baruti i raketna goriva - METODA TEST VAKUUM STABILNOSTI, Beograd, 2013.

\title{
Ispitivanje hemijske stabilnosti baruta i raketnih goriva metodom test vakum stabilnosti
}

\begin{abstract}
U ovom radu su prikazani rezultati ispitivanja jednobaznih $i$ dvobaznih baruta $i$ dvobaznih raketnih goriva koji su ispitivani češkim uređajem test vakuum stabilnosti. Za korišćenje ove metode neophodno je bilo jasno definisati uslove ispitivanja, odnosno: uslove pripreme uzoraka, odvage i same uslove eksperimenta. Hemijska stabilnost ispitivanih uzoraka određena je standardom, STANAG 4556.
\end{abstract}

Ključne reči: barut, jednobazni barut, dvobazni barut, dvobazno raketno gorivo, hemijska stabilnost, metoda ispitivanja, rezultati ispitivanja.

\section{Тестирование химической стойкости порохов и ракетных топлив методом испытаний вакуумной стабильности}

\begin{abstract}
В данной статье представлены результаты испытаний порохов одной базы и порохов двойной базы, а в том числе и ракетных топлив двойной базы, которые были испытываны чешским тест-оборудованием для испытывания вакуумной стабильности. Чтобы использовать этот метод, необходимо было чётко определить условия испытания, а именно: условия подготовки образцов, взвешивание и те же экспериментальные условия. Химическую стойкость испытываемых образцов определяли с помощью стандартного STANAG 4556.
\end{abstract}

Ключевые слова: порох, порох одной базы, порох двойной базы, ракетное топливо двойной базы, химическая стойкость, методы испытаний, результаты испытаний.

\section{Détermination de la stabilité chimique de poudre et des propergols par la méthode vacuum test stabilité}

\begin{abstract}
Dans ce papier on a présenté les résultats des recherches sur les poudres monobasiques et bibasiques ainsi que sur les propergols bibasiques examinés par le dispositif tchèque de vacuum test stabilité. Pour utiliser cette méthode il était nécessaire de définir précisément les conditions des recherches c'est-à-dire les conditions de préparations des échantillons, la sélection de la masse optimale des échantillons ainsi que les conditions des recherches mêmes. La stabilité chimique des échantillons testés a été déterminée selon la norme STANAG 4556.
\end{abstract}

Mots clés: poudre, poudre monobasique, poudre bibasique, propergol bibasique, stabilité chimique, méthode des recherches, résultats des recherches. 